\title{
Granzyme B
}

National Cancer Institute

\section{Source}

National Cancer Institute. Granzyme B. NCI Thesaurus. Code C104268.

Granzyme B (247 aa, $28 \mathrm{kDa}$ ) is encoded by the human GZMB gene. This protein plays a role in the mediation of cell-dependent cytotoxicity. 